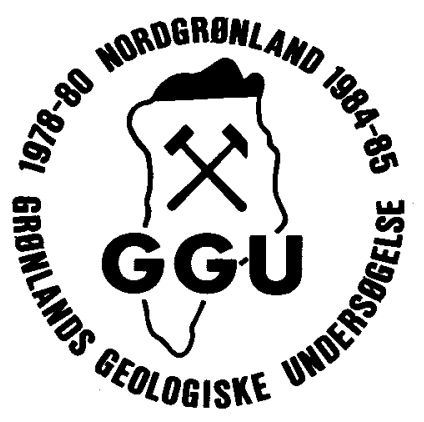

\title{
Cambrian - Lower Silurian stratigraphy in the fold and thrust zone between northern Nyeboe Land and J. P. Koch Fjord, North Greenland
}

\author{
N. C. Davis and A. K. Higgins
}

Brief description is given of observations on the Cambrian Lower Silurian outer shelf and slope deposits of central and western North Greenland. A provisional correlation is proposed between various units of the shallow marine Buen Formation and units of the deep-water Polkorridoren Group.

N. C. D., Department of Geology, University of Sheffield, Mappin Street, Sheffield SI 3JD, U. K.

A. K. H., Grønlands Geologiske Unders $\varnothing$ gelse, Øster Voldgade 10, DK-1350 Copenhagen K, Denmark.

The structure of the region between northern Nyeboe Land and the east side of central J. P. Koch Fjord (fig. 1) was shown in 1984 to be of typical thin-skinned fold-and-thrust type (Soper \& Higgins, 1985), quite distinct from that of the north-verging, multiply deformed orthotectonic zone to the north (see e.g. Bengaard et al., 1987). This southern zone of the North Greenland fold belt coincides with a region which appears to have been transitional between the shelf and basin for much of the Cambrian and Ordovician (Higgins \& Soper, 1985). Some of the rock units encountered pertain to the southern shelf (e.g. Portfjeld Formation, Buen Formation, lower units of the outer shelf and slope sequence), and others to the slope or basin (e.g. sequence transitional between Buen Formation and Polkorridoren Group, upper units of outer shelf and slope sequence).

In 1985 further observations were made on stratigraphy and structure, supplementing those made in the same region in 1984. This paper is mainly concerned with stratigraphical observations, and in particular possible correlation between units of the Buen Formation, a transitional Buen Formation/Polkorridoren Group sequence, and the Polkorridoren Group.

\section{Portfjeld Formation}

The Portfjeld Formation is a Lower Cambrian shelf dolomite sequence, generally of the order of $260-350 \mathrm{~m}$ thick, but east of J. P. Koch Fjord thickening northwards to more than $500 \mathrm{~m}$ (Higgins \& Soper, 1985). The upper levels of the sequence were examined at several localities, where the formation is brought up to exposure level in the cores of E-W trending, major anticlinal folds (fig. 1). 


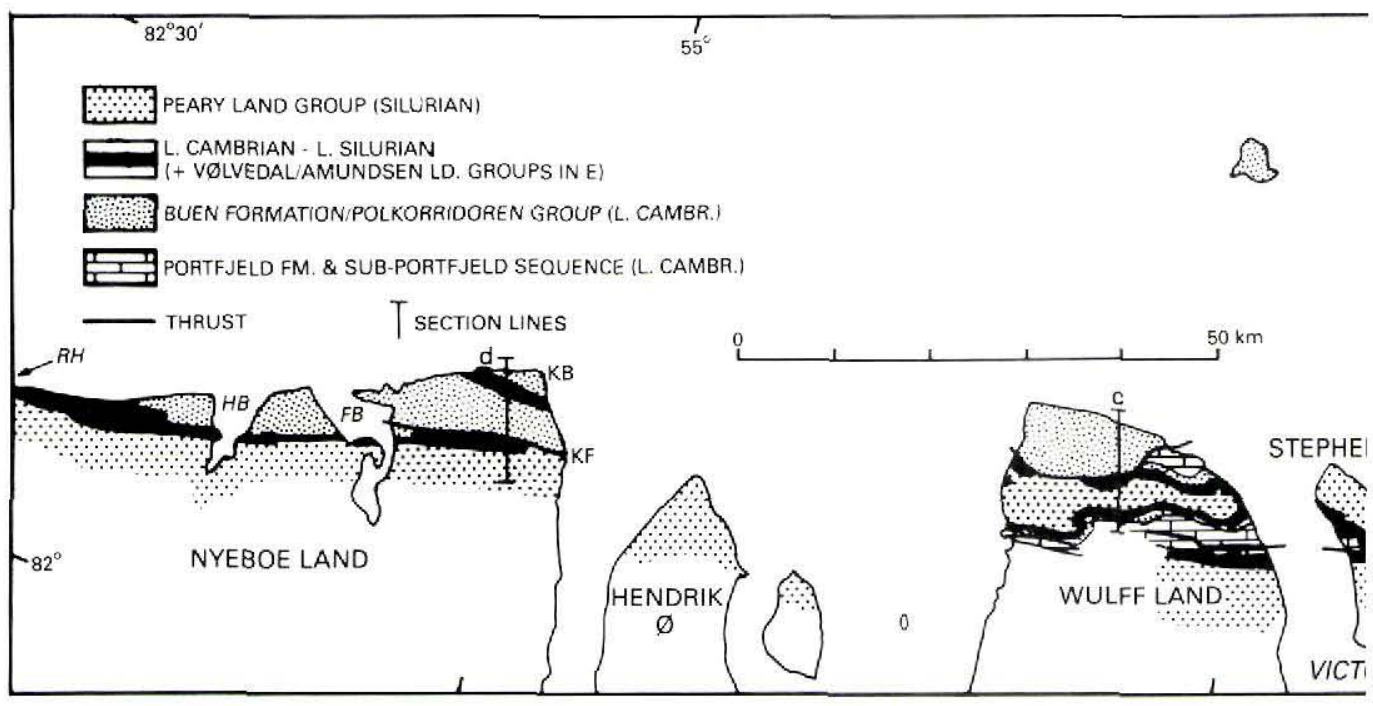

Fig. 1. Geological map showing distribution of some of the Lower Cambrian - Lower Silurian lithological units between Nyeboe Land and west Peary Land. HB: Hand Bugt; FB: Frankfield Bugt; KB: Kap

East of J. P. Koch Fjord, on the south side of a major anticline of Portfjeld Formation, the uppermost dolomite surface is made up of rotated and slumped dolomite blocks, apparently cemented and lithified prior to this disturbance; the blocks are infiltrated to a depth of $3 \mathrm{~m}$ by the lowest Buen Formation lithologies of siltstones and quartz sandstones.

In the Navarana Fjord anticline, isolated quartz grains occur in the uppermost dolomites in increasing numbers, and the lowest unit of the overlying Buen Formation is a $1 \mathrm{~m}$ bed of conspicuously well rounded quartz grains of coarse sand to granule size (Higgins \& Soper, 1985).

The upper dolomites of the Portfjeld Formation in the Wulff Land anticline also contain rounded quartz grains. On the north side of the anticline chaotic conglomerates of angular to rounded dolomite boulders in the Portfjeld/Buen Formation transition are enveloped by a siliciclastic matrix with abundant well rounded quartz grains.

Elsewhere in North Greenland, Peel \& Wright (1985) report a red-stained breccia of possible karstic origin at the top of the formation in southern Freuchen Land, while at the head of Victoria Fjord a unit consisting of brecciated and slumped masses of Portfjeld Formation is overlain by undisturbed Buen Formation sandstones and shales ( $\mathrm{H}$. F. Jepsen, personal communication, 1984; Surlyk \& Ineson, 1987).

All these features can be viewed as a reflection of a significant change in depositional environment at the end of Portfjeld Formation time, including uplift of the shelf carbonates, a hiatus in deposition, erosion and possible karst development, and exposure of new source areas which provided the siliciclastic detritus of the overlying Buen Formation and Polkorridoren Group. 


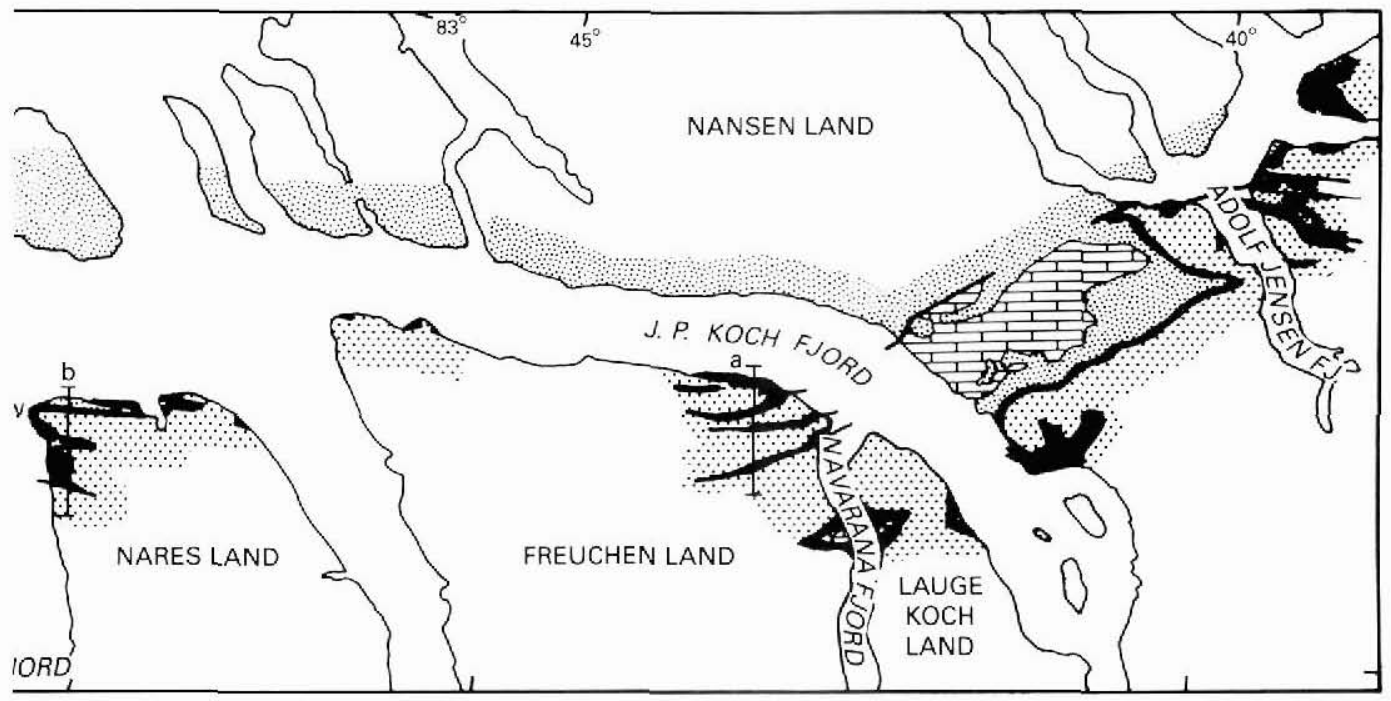

Bryant; KF: Kap Fulford; KW: Kap Wohlgemuth; RH: Repulse Havn. See fig. 3 for cross-sections.

\section{Buen Formation}

The clastic sediments overlying the Portfjeld Formation are shallow marine sandstones and shales of the Buen Formation (Surlyk \& Ineson, 1987); the much thicker deep-water basin equivalents are turbiditic sandstones and shales of the Polkorridoren Group (Surlyk et al., 1980; Surlyk \& Hurst, 1984; see also below, and Bengaard et al., 1987). The Buen Formation was examined particularly at two localities, east of central J. P. Koch Fjord and in northern Wulff Land, where the sequence in both cases is about $400 \mathrm{~m}$ thick.

The basal layers east of J. P. Koch Fjord are composed of well rounded, coarse, quartz sand grains, which infiltrate the upper surface of the Portfjeld Formation to variable degrees. In north Wulff Land the basal sandstones form a well marked unit, $40 \mathrm{~m}$ thick in the east; it thickens westwards across Wulff Land where it exhibits an intense rusty red staining.

East of central J. P. Koch Fjord two coarsening upward sequences, 50 and $80 \mathrm{~m}$ thick, overlie the thin basal sandstones. In northern Wulff Land two similarly developed sequences totalling $350 \mathrm{~m}$ overlie the basal sandstones (fig. 2). In the lowest parts of each coarsening upward sequence, black laminated shales occur, thin silt layers sometimes giving them a varved appearance. Upwards in the black shales, thin, fine-grained sandstones appear; they show lamination or ripple cross-lamination, and may be lenticular in form. The black shales give way upwards to greenish siltstones, with thin purple sandstone layers; the sandstones are well sorted, massive and occasionally show coarse tail grading. They give way to fine sandstones and in some sections to medium to coarse-grained, trough cross-bedded, channeled sandstones. These upper sandstones in each of the two upward coarsening sequences form prominent crags, of which that at the top of the second sequence is most prominent. Bioturbation is common in the siltstones and fine sandstones, but apart from a few Fordilla? (J. S. Peel, personal communication, 1986) no body fossils have been recovered. 
The upper part of the Buen Formation comprises a monotonous sequence of mudstone and siltstone, extensively bioturbated throughout, and from $60 \mathrm{~m}$ to more than $200 \mathrm{~m}$ thick; east of central J. P. Koch Fjord the Buen Formation thickens northwards across the major anticline of Portfjeld Formation from about $400 \mathrm{~m}$ to more than $700 \mathrm{~m}$, most of this increase being in the uppermost mudstones and siltstones. In some areas this upper sequence is divisible into a lower unit of greenish mudstones, and an upper unit of more compact black shale and siltstone. The top levels of the Buen Formation have yielded Lower Cambrian fossils east and west of central J. P. Koch Fjord and in north Wulff Land, including large sponges (mainly Choia hindei), trilobites, bradoriid ostracods and brachiopod fragments (identifications by J. S. Peel and J. K. Rigby, personal communications, 1986).

\section{Transitional Buen Formation/Polkorridoren Group sequence}

A thick clastic sequence transitional in type between the Buen Formation and the Polkorridoren Group is exposed along the northernmost extremity of north Wulff Land, where it is thrust southwards over normal Buen Formation developments, the Cambrian - Lower Silurian outer shelf and slope sequence and the Merqujôq Formation (fig. 3c). A similar transitional sequence is found in northern Nyeboe Land. The sequence in both areas is estimated to be at least $1200 \mathrm{~m}$ thick, about three times the normal Buen Formation thickness. However, as with the Buen Formation, a subdivision can be made into two coarsening upward units and an uppermost shale unit (fig. 2).

The lowest unit comprises in its lowest part laminated green shales and siltstones. Sandstones are infrequent, and occur as thin, lenticular, ripple cross-laminated beds, or fine to medium-grained graded sandstone in beds $6-45 \mathrm{~cm}$ thick. The proportion of siltstone and fine sandstone increases upwards, sandstone dominating at the top. Bedding and lamination deteriorate upwards with increasing intensity of bioturbation.

The second coarsening upward unit begins with about $20 \mathrm{~m}$ of purple coloured silty shales containing thin (4-12 cm), grey, quartz sandstone layers; the sandstones are well sorted, fine to medium-grained, and occasionally show normal grading. These pass upwards into $25 \mathrm{~m}$ of orange weathering fine sandstones and siltstones, laminated and thinly bedded, but extensively bioturbated. They are overlain by grey and lilac coloured siltstones and silty shales, and orange and black shale with rare fine to medium-grained sandstones; these $30-45 \mathrm{~cm}$ sandstone beds are evidently turbiditic with fluted and loaded bases, ripple cross-lamination and normal grading. Overlying greenish siltstones grade upwards over $200 \mathrm{~m}$ into fine to medium-grained sandstones. Bioturbation again increases upwards.

Black and purple shales (about $60 \mathrm{~m}$ thick) complete the sequence. Silt laminae are common. At the top of the sequence in northern Nyeboe Land the shales have a transitional contact over $7 \mathrm{~m}$ with limestones of the Cambrian - Lower Silurian outer shelf and slope sequence.

\section{Buen Formation - Polkorridoren Group correlation}

The general correlation of the Buen Formation with the Polkorridoren Group (Surlyk et al., 1980) has been confirmed by subsequent work (Surlyk \& Hurst, 1984; Higgins \& Soper, 1985). Here we propose a correlation of units within the two sequences.

While a close correlation is evident between the Buen Formation and the thicker transitional sequence of northern Wulff Land and northern Nyeboe Land (fig. 2), correlation 


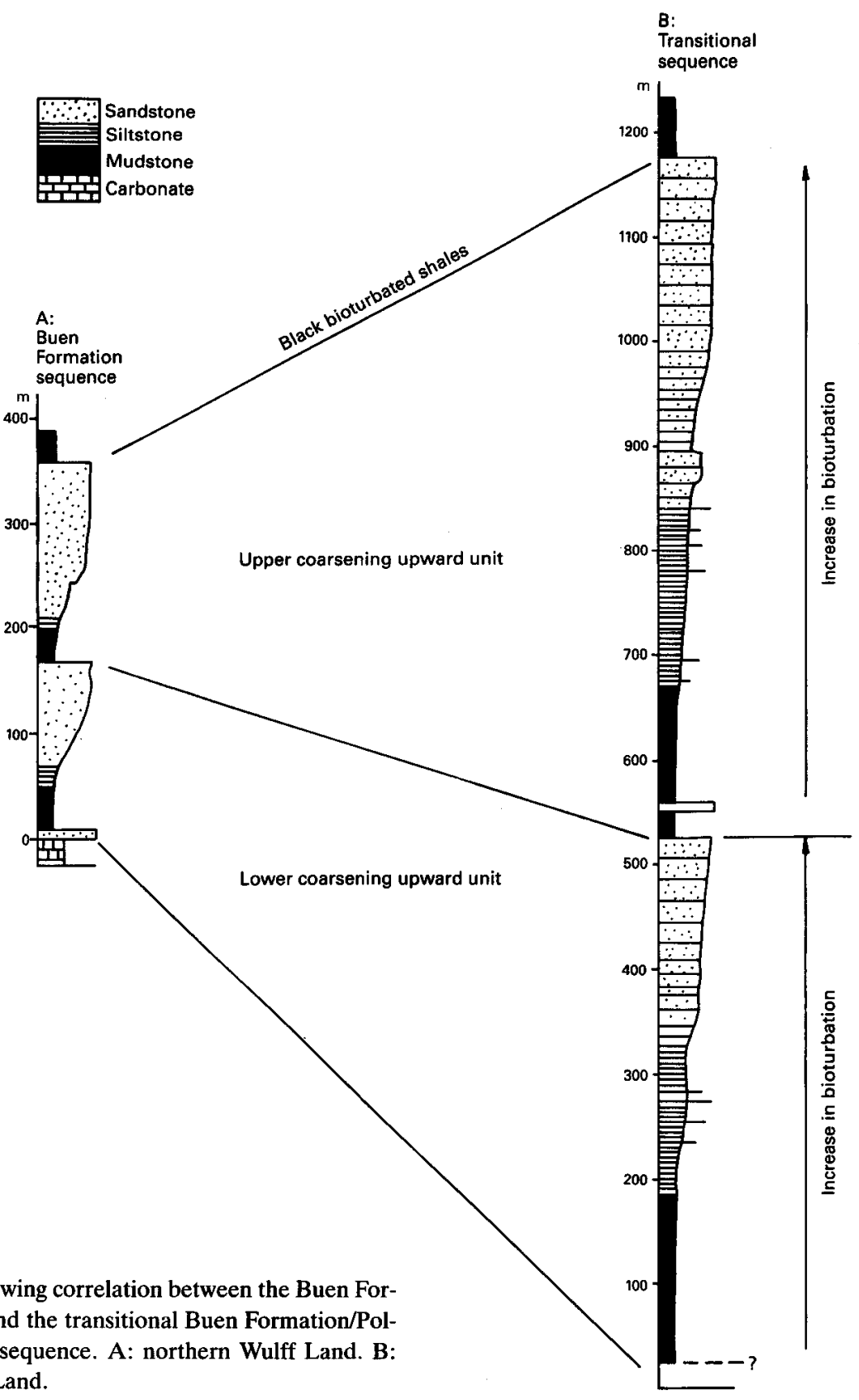

Fig. 2. Sections showing correlation between the Buen Formation sequence and the transitional Buen Formation/Polkorridoren Group sequence. A: northern Wulff Land. B: northern Nyeboe Land.

with units of the deep-water Polkorridoren Group succession is more tentative; this is because the region of the shelf-basin transition is generally that most disturbed by thin-skinned thrusting, such that major segments of the transition are hidden from view at present exposure levels. 
a) North-east Freuchen Land
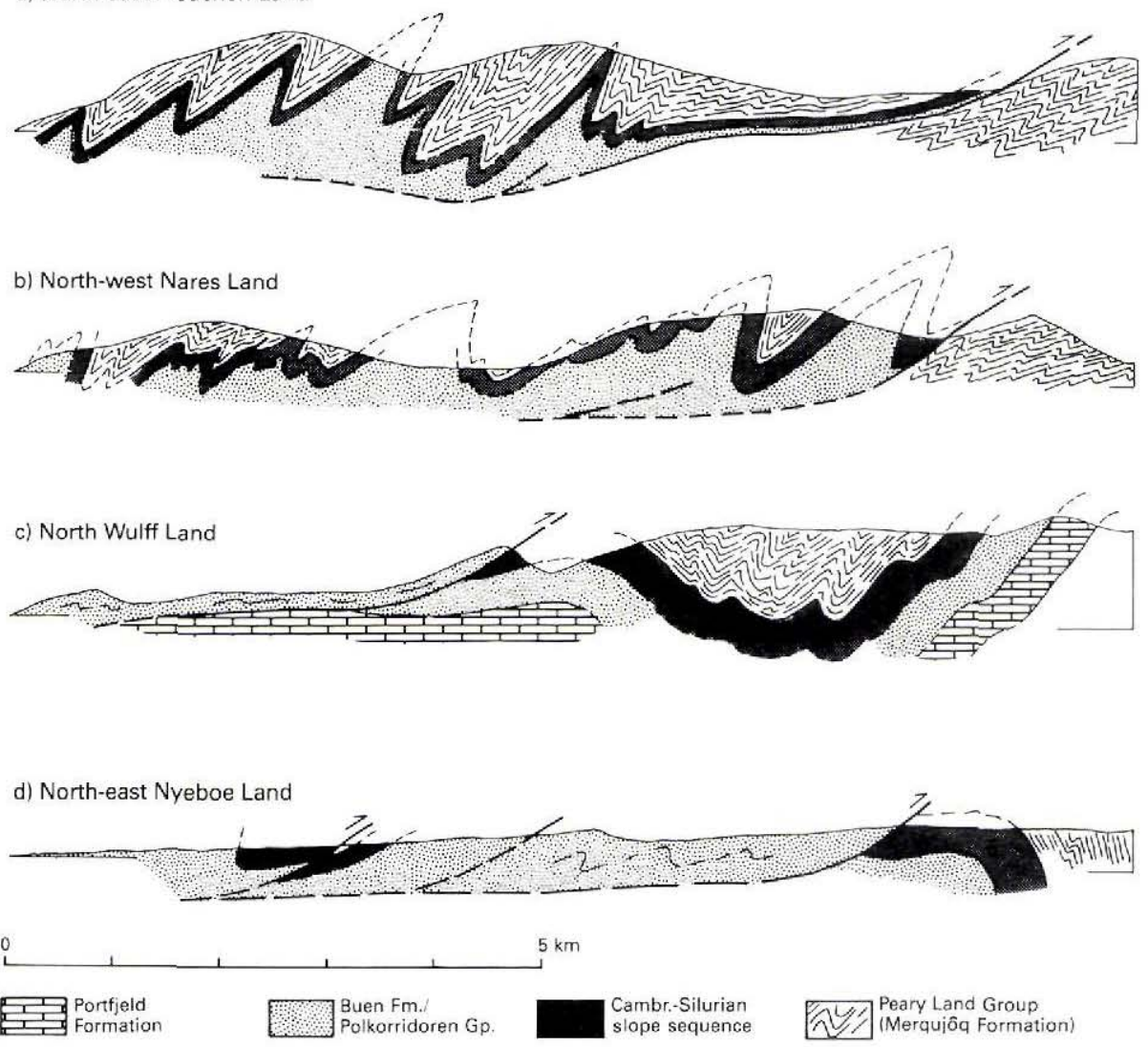

Fig. 3. Cross-sections showing structural style in the thin-skinned fold and thrust zone. For lines of cross-sections see fig. 1.

The subdivision of the Polkorridoren Group in the Nansen Land region is described by Bengaard et al. (1987). Neither their unit 1 (siltstone, shale and carbonate) nor their unit 2 (massive feldspar-rich sandstone turbidites) have any obvious correlatives in the Buen Formation of areas to the south, unless it be with the basal sandstones which in some areas are feldspathic. The influx of rich new sources of detritus into the basin, which accumulated as unit 2 turbidites, may correspond to a hiatus on the shelf represented by the uplift of the Portfjeld Formation, and reworking of the uppermost Portfjeld Formation surface.

The lithologies of unit 3/4 of the Polkorridoren Group (clean quartzitic turbidites with well rounded grains, green and purple shales with trace fossils) are on the other hand, similar to the lithologies of the upward coarsening cycles in both the transitional and Buen Formation sequences; a direct correlation is suggested. The mudstones of unit 5 (Frigg Fjord mudstones) of the Polkorridoren Group clearly correspond to the mudstones at the top of the Buen Formation; Hurst \& Surlyk (1980) in discussing this correlation remark on the similarity in their colouration and lithology (see also Higgins \& Soper, 1985). 


\section{Cambrian - Lower Silurian outer shelf and slope sequence}

The Lower Cambrian to earliest Silurian of the northern parts of Nyeboe Land, Wulff Land, Nares Land, Freuchen Land and west Peary Land is represented by a $58-475 \mathrm{~m}$ sequence of carbonates, shales and cherts, considered to represent the relatively starved deposits of the outer shelf and slope (Higgins \& Soper, 1985; Surlyk \& Ineson, 1987). The sequence overlies Buen Formation shales and is overlain by turbiditic sandstones of the Peary Land Group. Eight new sections were measured through the sequence in 1985. These confirm the four unit subdivision and also the northward thinning of the sequence recognised by Higgins \& Soper (1985).

Unit 1 comprises rubbly weathering, often nodular, limestones and shales. It was found to be unusually thick and richly fossiliferous in north-east Nyeboe Land south of Kap Bryant; olenellid trilobites and Serrodiscus were found in samples throughout a $70 \mathrm{~m}$ sequence. This locality has previously yielded a late Early Cambrian fauna (Peel, 1974, 1979; Dawes \& Peel, 1984; Peel \& Larsen, 1984). Five kilometres to the south another section yielded only hyolithids at a few levels. The suggestion by J. S. Peel (personal communication, 1984) that unit 1 is equivalent to the Aftenstjernes $\varnothing$ Formation of the shelf sequence has been confirmed by further work (Surlyk \& Ineson, 1987).

Unit 2 comprises dark weathering cherty shales, cherts, thin limestones and quartzites. It seems to form a thicker and more distinct unit in northern Nyeboe Land than elsewhere. J. S. Peel (personal communication, 1985) obtained Middle Cambrian trilobites from different levels of a well exposed sequence west of Hand Bugt. A suggested correlation of unit 2 with the Henson Gletscher Formation of the shelf sequence (J. S. Peel, personal communication, 1984) has been confirmed (Surlyk \& Ineson, 1987).

The carbonates of unit 3 include laminated dolomite mudstones, limestone conglomerates, and interbedded yellow dolomites and grey limestones; the interbanded limestones and dolomites become increasingly important westwards, where they commonly show disruption to intraformational flat-pebble conglomerates. Major units of the latter occasionally have the appearance of large-scale slumped bodies. Lower levels of unit 3 in Nyeboe Land east of Frankfield Bugt have yielded Middle Cambrian agnostid trilobites.

The uppermost sequence of cherts and cherty shales (unit 4) contains rich graptolite faunas ranging from Arenig to Late Llandovery in age, and has been broadly equated with the Amundsen Land Group of the Peary Land region (Higgins \& Soper, 1985; Surlyk \& Ineson, 1987). This unit thins from east to west across the region, from $100-150 \mathrm{~m}$ between $\mathrm{J}$. $P$. Koch Fjord and north Wulff Land, to $50 \mathrm{~m}$ east of Hand Bugt in northern Nyeboe Land; it appears to be absent west of Repulse Havn in northern Nyeboe Land.

In northern Nares Land, north-east Freuchen Land and east of central J. P. Koch Fjord, sections measured through the entire sequence total less than $150 \mathrm{~m}$, and comprise largely chert and cherty shale. In each case these sections are situated some 5-10 km north of sections of normal thickness $($ c. $450 \mathrm{~m})$; the reduction in thickness seems to be mainly due to the loss of unit 1 and 3 carbonates. These relatively thin starved sequences may represent lower slope accumulations in deep water, beneath carbonate compensation depth. 


\section{Structure}

The northward increase in intensity of deformation in the southern zone of the North Greenland fold belt is well seen in the walls of the N-S trending fjords, and has most recently been described by Soper \& Higgins (1985) and Larsen \& Escher (1985). The most intense deformation is seen in the northern parts of Freuchen Land, Nares Land, Wulff Land and Nyeboe Land where shortening was taken up by both tight south-facing folds and low angle thrusting, and may reach $60 \%$ (fig. 3). New thrusts were located in northern Nyeboe Land and northern Wulff Land in 1985. That in Wulff Land thrusts rocks of the deep-water transitional Buen Formation/Polkorridoren Group sequence southwards over normal developments of the shallow marine Buen Formation (fig. 3c). In north-east Nyeboe Land a major thrust can be traced for about $20 \mathrm{~km}$ between Frankfield Bugt and Kap Fulford. Near Kap Fulford it thrusts rocks of the transitional Buen Formation/Polkorridoren Group sequence against the outer shelf and slope sequence and Peary Land Group (fig. 3d).

\section{References}

Bengaard, H.-J., Davis, N. C., Friderichsen, J. D. \& Higgins, A. K. 1987: Lithostratigraphy and structure of the North Greenland fold belt in Nansen Land. Rapp. Gronlands geol. Unders. 133, 99-106.

Dawes, P. R. \& Peel, J. S. 1984: Biostratigraphic reconnaissance in the Lower Palaeozoic of western North Greenland. Rapp. Grønlands geol. Unders. 121, 19-51.

Higgins, A. K. \& Soper, N. J. 1985: Cambrian - Lower Silurian slope and basin stratigraphy between northern Nyeboe Land and western Amundsen Land, North Greenland. Rapp. Gronlands geol. Unders. 126, 79-86.

Hurst, J. M. \& Surlyk, F. 1980: Notes on the Lower Palaeozoic clastic sediments of Peary Land, North Greenland. Rapp. Grønlands geol. Unders. 99, 73-78.

Larsen, P.-H. \& Escher, J, C. 1985: The Silurian turbidite sequence of the Peary Land Group between Newman Bugt and Victoria Fjord, western North Greenland. Rapp. Grønlands geol. Unders. 126, $47-67$.

Peel, J. S. 1974: Lower Cambrian fossils from Nyeboe Land, North Greenland fold belt. Rapp. Grønlands geol. Unders. 65, 17 only.

Peel, J. S. 1979: Serrodiscus from northern Nyeboe Land. Rapp. Grønlands geol. Unders. 91, 116 only.

Peel, J. S. \& Larsen, N. H. 1984: Hadimopanella apicata from the Lower Cambrian of western North Greenland. Rapp. Grønlands geol. Unders. 121, 89-96.

Peel, J. S. \& Wright, S. C. 1985: Cambrian platform stratigraphy in the Warming Land - Freuchen Land region, North Greenland. Rapp. Grønlands geol. Unders. 126, 17-24.

Soper, N. J. \& Higgins, A. K. 1985: Thin-skinned structures at the basin-shelf transition in North Greenland. Rapp. Grønlands geol. Unders. 126, 87-94.

Surlyk, F. \& Hurst, J. M. 1984: The evolution of the early Paleozoic deep-water basin of North Greenland. Bull geol. Soc. Am. 95, 131-154.

Surlyk, F. \& Ineson, J. R. 1987: Aspects of Franklinian shelf, slope and trough evolution and stratigraphy in North Greenland. Rapp. Grønlands geol. Unders. 133, 41-58.

Surlyk, F., Hurst, J. M. \& Bjerreskov, M. 1980: First age-diagnostic fossils from the central part of the North Greenland foldbelt. Nature, Lond. 286, 800-803. 